https://doi.org/10.18485/kud_kiaz.2019.ch40

\author{
Севда Магеррамова \\ Д.ф.э. старший преподаватель \\ Азербайджанский Университет Языков
}

\title{
СТРАТЕГИЧЕСКОЕ РАЗВИТИЕ СЕЛЬСКОГО ХОЗЯЙСТВА АЗЕРБАЙДЖАНА
}

\begin{abstract}
SUMMARY
This article contains a brief description of the development of agriculture in Azerbaijan. It also considers the issues of determining the prospects for the development and formation of the new potential of agriculture. The expedient solution of agricultural problems is presented and the possibility of a quick transfer of the agricultural sector to a new level is suggested. In addition, special attention is paid to the development of the agrarian sector, its normative regulation and the identification of further prospects for its development.
\end{abstract}

Key words: Azerbaijan, agriculture, agrarian sphere, land reform, agrarian reform, form of ownership, privatization.

\section{Введение}

С развитием общественно-экономических формаций Азербайджана, развивалось и сельское хозяйство, история развития которой охватывает тысячелетний период. Образ жизни и культура народа данной территории годами выступала основным элементом в становлении сельского хозяйства. Развитие сельского хозяйства как одной из основных отраслей азербайджанской экономики является гарантом обеспечения социальной и политической стабильности в республике и постоянно находится в центре внимания. 
Сельское хозяйство является одним из ключевых направлений аграрной промышленности. Его основная задача - обеспечить продовольствием население страны, добиться ускорения социально-экономического развития во всех регионах, произвести сырье для перерабатывающей промышленности, устранить диспропорции между сельскохозяйственной и животноводческой продукцией, рассмотреть необходимость сельскохозяйственного производства и переработки для создания инфраструктуры.

Если обратиться к истории, то Азербайджан всегда считалась аграрно-промышленной страной. Еще во времена СССР Азербайджан не только являлся нетто-экспортером ряда важных сельхоз культур, но и обладал развитыми субсекторами наиболее важных видов сельскохозяйственного производства. Но в связи с армянской агрессией и не менее вредоносной для Азербайджана горбачевской политики перестройки сельское хозяйство постепенно начало терять свои позиции, началось сокращение производства. Именно поэтому оказалось интересным, исследовать основные моменты современного состояния сельского хозяйства в стране.

Кризис в сельском хозяйстве и спад его производства постоянно наносит тяжелый удар по всей экономике, поскольку приводит к потере огромного количества бесплатных природных ресурсов, но эти потери приходится оплачивать при импорте продовольствия.

Начиная с начала XXI века, была принята Декларация о восстановлении государственной независимости Азербайджанской Республики, и дата от 18 октября 1991 года считается днем восстановления независимости нашей страны. Принятая в Советском союзе система зависимой экономики постепенно пришла к упадку, и экономика Азербайджана дошла до кризисной ситуации. Для вывода страны из такового положения целесообразно было провести ряд реформ, которые восстановили бы экономическую стабильность страны на новых основах. 
Согласно международной практике главным элементом становления экономики страны выступает сельскохозяйственная отрасль, которая охарактеризовывает уровень становления в стране национальной экономики. Основной задачей Азербайджана было вывести аграрный сектор из данного положения, т.к. к 1991-1993 годам данная сфера была полностью развалена, и производство упало до самой крайней отметки. Следовательно, главой государства была предложена мера по выводу государства из крайне нестабильного положении. Главными критериями ускоренного развития сельского хозяйства являлись использование самих природных ресурсов страны, а именно сама плодородная почва, умеренный климат и др.

Многолетний опыт высокоразвитых стран показывает, что в улучшение управления агропромышленным комплексом существенную роль играет разгосударствление, развитие свободных хозяйственной деятельности и предпринимательства. Следует отметить, что предпринимательства является главным элементом при проведении экономические реформы [8].

Следовательно, в стране за этот период активно стала реализоваться аграрная реформа. Проведение реформ в аграрном секторе был не случаен, т.к. уровень развития национальной экономики принято считать основным фактором. В таком случае прежняя экономическая система была заменена новыми производственными отношениями, а управление сельским хозяйством адаптировано к требованиям перехода к рыночным отношениям. Старт курсу аграрных реформ был дан с Нахичеванской Автономной Республики под руководством Гейдара Алиева, которая в дальнейшем охватила весь аграрный сектор республики. В результате аграрных реформ, начавшихся с земельной реформы, сформировались новые производственные отношения, основанные на частной собственности, земля была передана в собственность крестьянам, начались процессы формирования современной бизнес 
среды, в аграрном секторе были заложены основы необходимых условий для реальной кооперации.

Известно, что основной стратегической линии развития предпринимательства является приватизация, получающим настоящее время широкое распространение. Правильная практика приватизации - это основное средство предпринимательской деятельности и выход экономики из тяжелого кризиса. Поэтому при выборе вариантов приватизации основной упор должен делаться не на фискальный подход, а на экономическую целесообразность. И следуя этому, в Азербайджане образовались совершенно новые формы собственности, сформировались новые взаимоотношения, которая привела к приватизации государственной собственности. В январе 1993 года Милли меджлис принял закон о приватизации государственной собственности в Азербайджане, который выступал юридической основой для проведения разгосударствления собственности. Тот период ограничивается принятием только закона, и никаких других мер по реализации приватизации не было принято. Возникла только вероятность реализовывать эту деятельность на базе данного закона, которая создала юридическую основу для реформирования отношений собственности. Также Государственный комитет по имуществу проявлял абсолютное бездействие, не была представлена ни одна программа приватизации, не было нормативного закрепления приватизации. Даже если были определенные документы по проведению приватизации, то их было очень мало, т.е. нужный масштаб не охватывался. Мало того, но и Кабинет министров Азербайджана не отнесся к этому делу как нужно, он препятствовал принятию определенных мер, которые смогли бы урегулировать процесс приватизации.

В процессе приватизации особое внимание необходимо было уделять приватизации частной собственности, т.к. оно способствует повышению эффективности производства с помощью использования конкуренции, а также 
производительности труда, которая будет способствовать достижению изобилия высококачественной экологически чистой сельскохозяйственной продукции

Начиная с 1995 года, основной акцент внимания был сконцентрирован на процессе по переходу к рыночным отношениям сельского хозяйства. На основе этого были приняты законы Азербайджанской Республики «Об основах аграрной реформы», «О реформе колхозов и совхозов», а также Закон Азербайджанской Республики «О земельной реформе» от 16 июля 1996-го года, Закон Азербайджанской Республики «О государственном земельном кадастре, мониторинге земель и землеустройстве» от 22 декабря 1998-го года, Закон Азербайджанской Республики «Об аренде земли» от 12 марта 1999-го года, утвержденный Законом Азербайджанской Республики от 25 июня 1999-го года «Земельный Кодекс Азербайджанской Республики», Закон Азербайджанской Республики «О земельном рынке» от 7 мая 1999-го года, а также более 52 указов, законов и других нормативно-правовых актов, которые создали основу для воплощения в жизнь земельной реформы.

За небольшой период в Азербайджане были осуществлены реформы в области аграрного сектора, в частности же земельные реформы, которые повысили темпы формирования аграрного хозяйства. В тот момент, была восстановлена историческая справедливость в отношении земли - она была безвозмездно передана сельчанам, и появились необходимые условия для развития выгодного аграрного хозяйства. Кроме этого стали приватизированы наиболее пахотно-пригодные и качественные территории и всем жителям города, проживающих на территории республики, не зависимо от места жительства было дано право использования и аренды земли, в то же время, каждый гражданин Азербайджана мог иметь право в купли-продажи земли и заключении договоров и сделок, связанных с землей. 
Таким образом, в процессе реформ обусловилось 3 формы собственности: государственная - 4,9 миллиона га, которой было передано $56,7 \%$ из общего земельного фонда, муниципальная - 2 миллиона га и 1,7 миллиона га было передано в частную собственность.

Следовательно, реализовались ключевые перемены в социальном и отраслевом содержании аграрного хозяйства. Крупнейшие хозяйственные формы были заменены многочисленными хозяйственными субъектами различного происхождения, т.е. от государственной формы собственности осуществился переход к частной форме собственности над земельными угодьями, скотом, производственной и непроизводственной сферами, сельскохозяйственной техникой. В данной ситуации число сельскохозяйственных производителей насчитывает $1.208,7$ человек. Из них - 99,98\% частные производства, $0,02 \%$ - государственные. А также, насчитывалось 78.648 дачных производителей, занимающихся производством, обработкой и реализацией различного перечня сельскохозяйственной продукции.

Также одной из основных задач, которое должно применяться в сельском хозяйстве является организация сельскохозяйственного производства, дальнейшее укрепление и развитие института фермерства, являющееся основной институциональной формой в интенсивном увеличении объема продукции, а также повышения урожайности культур и продуктивности животноводства.

За счёт модернизации экономики Азербайджана, в том числе и аграрного хозяйства, Азербайджан вступил в XXI век как стабильная страна с политической и с экономической позиции. Азербайджан, переживающий период бурного динамичного становления, за исторически небольшой период времени прошел путь большого прогресса, который отразился в истории Азербайджана как период расцвета культуры, формирования и обогащения всех ее сфер. 
Особое же внимание в Азербайджанской Республике уделялось проведению аграрные реформы, где широкое внимание было уделено земельной реформе. Это увеличило темпы развития аграрного хозяйства, возрастало изготовление продукции сельского хозяйства, обозначились усовершенствования в материальном состоянии производителей, обстоятельствах и условиях производственной деятельности, и в конечном итоге, осуществлялась многовековая мечта азербайджанского земледельца быть владельцем земли. Таким образом, земля была безвозмездно переда в право собственности сельскому населению, и возникли реальные условия для формирования нового отношения земледельца к земле.

Осуществление реформ в сельскохозяйственном секторе, основополагающем существенную долю экономики Азербайджана, было задачей как сколь значимой, так и столь и сложной. Аграрный сектор считается основной составляющей частью не только нашей экономики, но и является главной сферой экономики любой страны. Преобразования в сельском хозяйстве не только послужат формированию экономики в общем, но и дадут возможность гарантировать бесперебойное снабжение населения страны продуктами питания [10].

За определенный период времени в Азербайджане на макроэкономическом уровне была представлена удивительная статистика (таблица 1). В таблице 1 отражены основные макроэкономические показатели Азербайджанской Республики за 1995-2003 года (в \% к предыдущему году). По таблице видно, что все показатели от 1995 года по 2003 год отражают положительные результаты, и наглядно видно как возрастают показатели и сельскохозяйственной продукции от $93 \%$ до $106 \%$, т.е. за 9 лет макроэкономический показатель повысился на $13 \%$. 
Основные макроэкономические показатели Азербайджанской Республики

(в \% к предыдущему году)

Таблица 1

199519961997199819992000200120022003

Валовой внутренний продукт

$88,2 \quad 101,3105,8$ 110,0 107,4 111,1 109,9 110,6 111,2

Продукция промыш-

ленности

$\begin{array}{lllllllll}79 & 93 & 100,3 & 102 & 104 & 107 & 105 & 104 & 106\end{array}$

Продукция сельского хозяйства

$\begin{array}{lllllllll}93 & 103 & 94 & 106 & 107 & 112 & 111 & 106 & 106\end{array}$

Инвестиции в основ-

ной капитал

$\begin{array}{lllllllll}82 & 212 & 139 & 123 & 98 & 103 & 121 & 184 & 174\end{array}$

Перевозки

грузов

$\begin{array}{lllllllll}91 & 100,7 & 117 & 120 & 133 & 121 & 117 & 109 & 112\end{array}$

Оборот розничной

торговли

$\begin{array}{lllllllll}102 & 114 & 115 & 110 & 113 & 109,8 & 110 & 109,5 & 111\end{array}$

Индексы цен произво-

дителей промышлен- $\quad \begin{array}{lllllllll}561 & 196 & 130 & 88 & 94 & 130 & 103 & 99 & 117\end{array}$

ной продукции

Индексы потребитель-

ских цен

$\begin{array}{lllllllll}512 & 120 & 104 & 99 & 91 & 102 & 102 & 103 & 102\end{array}$

Экспорт в страны

Содружества

$\begin{array}{lllllllll}104 & 102 & 130 & 61 & 91 & 111 & 95 & 109 & 136\end{array}$

Экспорт в другие

страны

$\begin{array}{lllllllll}93 & 97 & 118 & 93 & 192 & 210 & 139 & 92 & 117\end{array}$

Импорт из стран Со-

дружества

$\begin{array}{lllllllll}47 & 149 & 103 & 115 & 80 & 115 & 119 & 146 & 131\end{array}$

Импорт из других

стран

$\begin{array}{lllllllll}150 & 141 & 71 & 152 & 106 & 112 & 124 & 103 & 175\end{array}$

Источник: [13].

Исследования показывают, что устойчивое развитие аграрного сектора и формирование устойчивой аграрной экономики напрямую связаны с правильной организацией его регулирующих механизмов. С этой точки зрения изучение и анализ государственного регулирования на устойчивое развитие имеет большое научное и практическое значение. Государственное регулирование, кото- 
рое считается одной из основных функций государства, исторически находилось в центре внимания экономистов и отдельных государственных деятелей.

Заключение. Подводя итог, следует отметить, что Азербайджан за годы независимости достиг существенного прогресса в развитии сельского хозяйства. Основную роль в этом играет целенаправленная государственная политика, которая стала важным звеном в превращении аграрного сектора в одну из ведущих отраслей экономики страны.

\section{Список литературы:}

Указы и распоряжения Президента Азербайджанской Республики. Баку, 1995-1999.

Ахмедов Н.Г. Развитие экономики Нахичеванской АР. - Баку, 2008.

Вердиев А.Д. Создание крестьянско-фермерского хозяйства в Азербайджане. - Баку, 1996.

Дроздков А.В. Аграрные реформы в России: содержание, последствия: Учебное пособие. - Омск: Изд-во Сибади, 2008.

Ирада Гусейнова. Гейдар Алиев - от политического руководителя к общенациональному лидеру. Баку, «Тахсил», 2005.

Нагиев А., Новрузов В., Аллахвердиев Г., Алирзаев А. Гейдар Алиев и экономика Азербайджана. - Баку, 1998.

Серова Е.В. Аграрная Экономика. М.: ГУ ВШЭ, 1999.

Становление рыночных отношений в Азербайджане в условиях трансформации социально-экономической системы (коллективная монография). - 1998.

Salahov S. Aqrar sferada dövlət təmzimlənməsinin konseptualəsasları və prioritetləri, Bak1, 2002.

Heydər Oliyev. Müstəqillik yollarında. Çıxışlar, nitqlər, bəyanatlar, məktublar, müsahibələr, məruzələr, müraciətlər. I - IV c., Bakı, 1997.

Heydər Oliyev. Müstəqilliyimiz əbədidir. I - IV c., Bak1, 1998.

www.stat.gov.az

www.cisstat.com 


\section{PЕЗЮМЕ}

Данная статья содержит краткую характеристику развития сельского хозяйства в Азербайджане. Также рассматриваются вопросы определения перспектив развития и становления нового потенциала сельского хозяйства. Представлено целесообразное решение сельскохозяйственных проблем и предположена возможность быстрого перевода аграрного сектора экономики на новый уровень. Кроме этого, особое внимание уделено развитию аграрного сектоpa, его нормативному регулированию и выявлению дальнейших перспектив его развития.

Ключевые слова: Азербайджан, сельское хозяйство, аграрная сфера, земельная реформа, аграрная реформа, форма собственности, приватизация. 